\title{
Radionuclides in radiation-induced bystander effect; may it share in radionuclide therapy?
}

\section{Minireview}

M. WIDEL*

Biosystems Group, Institute of Automatic Control, Faculty of Automatic Control, Electronics and Computer Science, Silesian University of Technology, 44-100 Gliwice, Poland

*Correspondence: maria.widel@polsl.pl

\section{Received October 10, 2016 / Accepted February 1, 2017}

\begin{abstract}
For many years in radiobiology and radiotherapy predominated the conviction that cellular DNA is the main target for ionizing radiation, however, the view has changed in the past 20 years. Nowadays, it is assumed that not only directed (targeted) radiation effect, but also an indirect (non-targeted) effect may contribute to the result of radiation treatment. Non-targeted effect is relatively well recognized after external beam irradiation in vitro and in vivo, and comprises such phenomena like radiation-induced bystander effect (RIBE), genomic instability, adaptive response and abscopal (out of field) effect. These stress-induced and molecular signaling mediated phenomena appear in non-targeted cells as variety responses resembling that observed in directly hit cells. Bystander effects can be both detrimental and beneficial in dependence on dose, dose-rate, cell type, genetic status and experimental condition. Less is known about radionuclide-induced non-targeted effects in radionuclide therapy, although, based on characteristics of the radionuclide radiation, on experiments in vitro utilizing classical and 3-D cell cultures, and preclinical study on animals it seems obvious that exposure to radionuclide is accompanied by various bystander effects, mostly damaging, less often protective. This review summarizes existing data on radionuclide induced bystander effects comprising radionuclides emitting beta- and alphaparticles and Auger electrons used in tumor radiotherapy and diagnostics. So far, separation of the direct effect of radionuclide decay from crossfire and bystander effects in clinical targeted radionuclide therapy is impossible because of the lack of methods to assess whether, and to what extent bystander effect is involved in human organism. Considerations on this topic are also included.
\end{abstract}

Key words: radionuclides, alpha and beta particles, Auger electrons, radionuclide targeted therapy, radionuclide induced bystander effects

Radiation-induced bystander effect (RIBE) is a nontargeted effect emerging in non-irradiated cells as different biological changes elicited by molecular signals secreted from radiation exposed neighbors [1-4, and references therein]. RIBE is communicated through cell-to-cell gap junctions or by extracellular environment, and typically refers to the damaging events such as reduced clonogenic survival $[5,6]$, increased sister chromatid exchange [7,8], formation of micronuclei and cell death via apoptosis and necrosis [9-12], all presented in vitro, although similar events appear also in vivo. Many preclinical studies revealed the appearance of bystander effect and abscopal (out of field effect) in vivo (reviewed by
[13]. The abscopal effect is an immune-mediated phenomenon. Preclinical studies and clinical cases of beneficial abscopal effects published so far suggest that radiotherapy acts synergistically with targeted immune treatment and this seems to be a field for clinical manipulation. Radiationinduced genomic instability disclosed as lethal mutations, unstable chromosomal aberrations and delayed reproductive death is also the manifestation of bystander effect signaling [14]. On the other hand, bystander effect may also appear as radioadaptive and radioprotective effects [11, 15-17]. Reactive oxygen species (ROS), nitric oxide, lipid peroxidation end products, cytokines like interleukin-6 (IL-6), interleukin-8 
(IL-8), transforming growth factor beta (TGF- $\beta$ ), tumor necrosis factor alpha (TNF- $\alpha$ ) have all been implicated in bystander signaling either via intercellular gap junctions, or medium transfer mechanism [1, review]. Numerous studies of bystander effect in vitro and in vivo focus primarily on ionizing radiation from external sources including alpha particles microbeam, $\mathrm{X}$-rays and gamma rays. This is justified because of the widespread use of external beam irradiation in cancer radiotherapy and still unanswered question on bystander effect contribution to cancer cure or enhancement of normal tissue reaction. As all these aspects have been quite widely described in the literature, therefore in this review they will be inserted only if necessary. During last decades radionuclidebased targeted therapies have emerged as efficient tools for cancer treatment and radionuclide-generated bystander effect deserves an interest of radiobiologists and radiotherapists [ $[18$, 19]. This paper is thus a summary of the main hitherto studies concerning the radionuclide induced bystander effect in vitro and in animal experiments in vivo. Clinical look at radionuclide induced bystander effect is also being considered. In the view of increasing use of radionuclides in cancer diagnostic and radiotherapy, this issue seems to be gaining significance due to potential therapeutic efficacy and/or possible risk of normal tissue damage.

\section{Rationale to study radionuclide induced bystander effect}

Radionuclide therapy is utilized in the case of metastatic cancers or disseminated diseases when conventional radiotherapy is impossible due to tumor localization near to sensitive organ, or when chemotherapy is too toxic [20]. Radionuclide therapy is the targeted therapy applied in the treatment of different diseases such as thyroid malignancies, metastatic bone pain, hepatocellular carcinoma (HCC), neuroendocrine tumors (NETs), non-Hodgkin's lymphoma (NHL) and others (reviewed in [21]). It is especially attractive since radioactive isotopes bound to vectors e.g. monoclonal antibodies, can be specifically delivered to the tumor cells expressing a particular antigen, the treatment known as radioimmunotherapy (RIT) $[22,23]$. Two monoclonal antibodies directed to CD-20 antigen, ${ }^{90} \mathrm{Y}$-ibritumomab tiuxetan and ${ }^{131} \mathrm{I}$-tositumomab, are commonly used, usually after chemotherapy in the treatment of B-cell lymphoma [24-26]. Radionuclides can also be bound to other type vectors with affinity to specific tissue elements, or which can selectively achieve a particular target (targeted radionuclide therapy, TRT), e.g. the sodium/iodide symporter in thyroid tissue $[27,28]$. Radiolabeled bisphosphonates or calcium mimetic radioactive salts with affinity to bone [29] can target skeletal metastasis. Neuroendocrine tumors which naturally express the membrane-bound noradrenaline transporter (NAT), can be effectively targeted by $\left.{ }^{131} \mathrm{I}\right]$ meta-iodobenzylguanidine ([ $\left.\left.{ }^{131} \mathrm{I}\right] \mathrm{MIBG}\right)$, a stable, non-immunogenic analogue of adrenergic neuron blockers [30-33]. Targeted radiotherapy with $\left[{ }^{131} \mathrm{I}\right]$ MIBG seems also be a possible alternative form of radiation treatment of prostate cancer especially when could be combined with gene therapy transducing NAT to prostate cancer cells [34]. Recently, ${ }^{223} \mathrm{Ra}$-dichloride, the high linear energy transfer (high LET) alpha emitter was introduced for the treatment of prostate and breast cancer patients with skeletal metastases [35] and particularly in castration-resistant prostate cancer patients with symptomatic bone metastases, but without visceral metastatic disease [36]. In addition, strontium- $89\left({ }^{89} \mathrm{Sr}\right)$, the beta-emitter is used for palliative treatment of bone metastases [37].Targeted radiotherapy seems to be very attractive because different radionuclides that emit beta or alpha particles and Auger electrons, often associated with $\mathrm{X}$ or gamma rays may be bound to carriers specifically reaching the cells/tissues we are interested. When such radionuclides are accumulated in the targeted tissues, their decay should result in highly localized energy deposition, e.g. in the tumor cells and minimal irradiation of surrounding normal host tissues. However, while dosimetry for external irradiation sources is well established, this problem is more complicated in the treatment with isotopes due to their physical properties. Thus, linear energy transfer (LET) for radionuclides ranges from $0.2 \mathrm{keV} /$ $\mu \mathrm{m}$ for beta, $\mathrm{X}$, and g rays, $4-25 \mathrm{keV} / \mu \mathrm{m}$ for Auger electrons, to $50-230 \mathrm{keV} / \mu \mathrm{m}$ for alpha particles [20]. Penetration of different particles in the tissue is also variable, from a few $\mathrm{nm}$ to $\mu \mathrm{m}$ for Auger electrons, fifty to a hundred $\mu \mathrm{m}$ for alpha particles and from $\mu \mathrm{m}$ to $\mathrm{mm}$ for beta particles. Finally, the distribution of the radioactivity is heterogeneous in population of cells within the organ and whole organism or in subcellular compartments [20, 38]. However, due to "crossfire" action [2, 19], especially for emitters with penetration distance higher than cell diameters $(>10 \mu \mathrm{m})$ non-targeted cells can receive a biological effect from the decaying radionuclide retained in labeled cells, additionally to a molecular bystander signaling. If such communication led to intensification of damage within the tumor, a beneficial bystander effect would occur. However, due to crossfire between radionuclide targeted cancer cells and adjacent normal cells/tissue, or due to radionuclide transport and excretion, the normal tissues may be exposed to radiation and to bystander signaling carrying a health risk.

Many short-lived radionuclides are also applied in cancer diagnostics. E.g. in diagnostic of urological cancer metastases Technetium-99m $(\mathrm{T} 1 / 2=6 \mathrm{~h})$ emitting gamma rays is used in single photon emission computed tomography (SPECT), Fluoride-18 (T1/2=110 min) and Gallium-68 (T1/2=68 min) emitting beta particles are used in positron emission tomography (PET) [39]. Technetium 99m and Fluoride-18 are also used in detection of bone metastases in lung and other cancers [40]. One can expect that bystander effects may appear in this low dose diagnostic application, with yet unknown consequences, protective or potentially detrimental since data on low dose/ low dose-rate effects are divergent (reviewed by [18]). The use of low doses of the radionuclide (tens-few hundred $\mathrm{MBq}$ ) in diagnostic imaging and bio-distribution of the radionuclide followed by a high therapeutic dose (several GBq) may result in the adaptive response appearance [41]. The data on the radionuclide induced bystander effect are relatively sparse 
and refer mainly to the in vitro research and animal studies, which are reviewed below.

\section{In vitro studies of radionuclide induced bystander effect}

Beta particles induced bystander effect. Several studies performed in vitro used tritium labeled nucleobases like deoxythymidine $\left({ }^{3} \mathrm{HTdR}\right)$ or deoxycytidine $\left({ }^{3} \mathrm{HdC}\right)$. Tritium emits short-range $\beta$ particles with a spectrum of energy ranging from $0-18.6 \mathrm{keV}$ (the mean $5.7 \mathrm{keV}$ ), and it has a range of $\sim 1 \mu \mathrm{m}$ in water, thus when it is localized in the cell nucleus, it generally does not irradiate neighboring cells [42 and references therein]. Incorporated ${ }^{3} \mathrm{HTdR}$ exerts damaging effects on cells including inhibition of cell proliferation [43], suppression of clonogenicity [44], cell death [45], chromosome aberrations [46, 47], DNA strand breaks [48], and cell-cycle arrest [49]. Bishayee et al. [50] performed one of the first studies on radionuclide induced bystander effect. They used tritiated thymidine to label Chinese hamster fibroblasts V79 line, then mixed them in different proportion with unlabeled V79 cells, and prepared multicellular clusters of about $1.6 \mathrm{~mm}$ in diameter by gentle centrifugation. After $72 \mathrm{~h}$ incubation cells were seeded for colony formation to measure the bystander effect. The short range of the ${ }^{3} \mathrm{H}$-emitted $\beta$-particles were restricted to labelled cell only, and did not allow a cross-irradiation of unlabeled cells. In the case of $100 \%$ labeling, the survival of cells in the cluster was simply dependent on cluster activity, and lindane (the intercellular gap-junction blocker) had no effect on the response. However, in the case of 50\% labeling cells surviving fraction decreased more than could be anticipated on the base of labeling, and lindane effectively inhibited cell killing. Thus, bystander signaling had to be undoubtedly involved in observed radioisotope-induced bystander effect and was transmitted through gap junctions [50]. The same group repeated the experiments and showed that even at the lower percentage of radiolabeled cells (10\%) bystander effect was observed, and not only lindane but also radical scavenger DMSO protected bystander cell killing [51]. This point out the free radicals as initiators of bystander communication, which is conveyed by intercellular gap-junctions.

Gerashchenko and Howell [42] investigated possible anti-proliferative bystander effects caused by intracellular irradiation with incorporated ${ }^{3} \mathrm{HTdR}$ in rat liver epithelial cells (WB-F344). Tritium-labeled cells (absorbed doses 0.14$1.7 \mathrm{~Gy}$ ) mixed with unlabeled (bystander) cells (stained with fluorescent marker) in a ratio of 1:1 and co-cultured for $24 \mathrm{~h}$ induced bystander effect in unlabeled cells manifested as enhanced (by $\sim 10 \%$ ) cell growth. This effect had to be triggered by soluble factors emitted by radionuclide labeled cells although putative factors causing growth stimulation of bystander cells were not defined. The authors speculate, based on data concerning external irradiation bystander effect signaling, that ROS, nitric oxide, plasma membrane receptors and alterations in the extracellular matrix of radiolabeled cells may initiate a proliferative response in adjacent bystander cells [41]. Pinto et al. [52] evaluated the cell cycle transition of human normal fibroblasts (AG1522) after incorporation of ${ }^{3} \mathrm{H}$-deoxycitidine $\left({ }^{3} \mathrm{HdC}\right)$ in 3-dimensional (3-D) co-culture on porous and biocompatible scaffold. Based on the flow cytometry cumulative labeling index assay, they found that cells labelled by ${ }^{3} \mathrm{H}$ bound to nucleus were delayed in G2 and subsequently in G1, in a dose-dependent manner (from 0.02 to $0.32 \mathrm{~Gy} / \mathrm{h}$ corresponding to $1.5-22 \mathrm{mBq}$ per labelled cell). However, no delay occurred in progression through G1 of bystander cells co-cultured with the labelled cells.

Adaptive response in bystander AG1522 fibroblasts in 3-D co-cultures containing tritium-labeled $(<16 \%)$ and unlabeled cells was also investigated [53]. To evaluate an adaptive bystander response, the ${ }^{3} \mathrm{HdC}$-labeled and unlabeled cells were co-cultured for 3 or $24 \mathrm{~h}$ and then were challenged with $4 \mathrm{~Gy}$ of gamma rays. When the average dose-rate in ${ }^{3} \mathrm{HdC}$-labeled cells was $0.04-0.37 \mathrm{~Gy} / \mathrm{h}$ (average accumulated dose $0.14-10$ Gy), no statistically significant stressful bystander effects an adaptive bystander effects were observed as measured by magnitude of the G1 arrest, micronucleus formation, or changes in mitochondrial membrane potential. Authors suppose that higher dose rates and/or higher LET may be required to induce bystander effects in this experimental co-culture system, and probably lower dose rates and challenge doses may be required to induce adaptive bystander responses.

The radionuclide-induced bystander mutagenesis was also documented in 3-D culture model $[54,55]$. Spheroids composed of labeled with tritiated thymidine $\left(\left[{ }^{3} \mathrm{H}\right] \mathrm{dTTP}\right)$ Chinese hamster ovary $(\mathrm{CHO})$ cells and human hamster hybrid $\left(\mathrm{A}_{\mathrm{L}}\right)$ cells were used to investigate bystander genotoxicity. This low LET $\beta$ emitter at dose $100 \mu \mathrm{Ci}$ induced high, 14-fold increased mutations in the non-irradiated $\mathrm{A}_{\mathrm{L}}$ cells compared with control, and simultaneously a decreased clonogenic survival. The DMSO or lindane reduced significantly the mutation incidence indicating that reactive oxygen species and intercellular gup junctions are engaged in bystander effect transmission.

Auger electron-induced bystander effects. The Auger electron emitters are frequently used in nuclear medicine. Examples include among others ${ }^{99} \mathrm{Tc},{ }^{123} \mathrm{I},{ }^{125} \mathrm{I}$. The iodine- 125 is the known Auger electron emitter, which toxicity depends on cellular localization. When incorporated into DNA it induces very efficiently direct killing, DNA double strand breaks and chromosomal aberrations which subsequently might generate bystander effects [56]. Thus, when incorporated into nucleus its radiotoxicity towards DNA can be compared with radiotoxicity of high LET alpha particles, but when localized in cytoplasm ${ }^{125} \mathrm{I}$ results in toxicity typical for low LET radiation $[57,58]$. Howell and Bishayee [57] investigated the biological effects of non-uniform distributions of DNA-incorporated ${ }^{125}$ I in Chinese hamster V79 fibroblasts using a 3-D culture. Multicellular clusters of $\sim 1.7 \mathrm{~mm}$ diameter were formed by gentle centrifugation of labeled with ${ }^{125}$ I-iodo-2-deoxyuridine (125IUdR) cells mixed with unlabeled cells at different proportions. When $100 \%$ of the cells were labeled, the survival 
fraction was exponentially dependent on the mean radioactivity per labeled cells, but the two-component survival curves were observed when either 50 or $10 \%$ of the cells were labeled. These two-component survival curves resulted from non-uniform distribution of radiation in the clusters. The highly localized in DNA energy deposition caused by ${ }^{125} \mathrm{I}$ decay resulted in very high equivalent doses delivered to the labeled cells, and low equivalent doses delivered to the unlabeled cells. Furthermore, the cell survival in the case of $50 \%$ or $10 \%$ labeled cells was much lower than predicted from dosimetry estimation of cross irradiation indicating a share of bystander effect in cell killing. However, it cannot be excluded that DNA/125IUDR or other radioactive molecular products released from damaged cells can additionally target neighbor cells directly, although this possibility is not considered by authors. The secretion of radiolabeled DNA derivatives resulting from damaged cells could be probably partly responsible for the different ability of various cells to induce a bystander effect observed by Akadugu et al [59]. In the studies performed on human breast carcinoma MDAMB-231 or MCF-7 cells using 3-D cell culture on carbon scaffold they demonstrated the capacity of ${ }^{125} \mathrm{IUdR}$ to induce lethal bystander effects in human breast cancer cells MCF-7 line but not in MDA-MB-231 cell line indicating that the bystander response is cell type dependent.

The anti-proliferative bystander effect of ${ }^{125}$ I-labeled human lymphocytes towards LS174T colon adenocarcinoma cells both in direct co-culture and in media transfer experiments was observed by Mamlouk et al. [60]. Cancer cells were mixed with lethally labeled (previously stimulated with phytohemagglutinin) lymphocytes in proportions: 1:0, 1:0.25, 1:0.5, 1:1, 1:2.5, and 1:5. The LS174T cell growth inhibition increased with increasing fraction of labeled lymphocytes. Clonogenic survival also decreased when cancer cells were treated by medium harvested from co-culture of another pool of cancer cells with ${ }^{125}$ I-labeled lymphocytes. Moreover, in the media harvested from the 1:1 co-cultures of tumor cells and ${ }^{125} \mathrm{I}$-labeled lymphocytes in which an inhibitory bystander effect was observed, an increased expression levels of tissue inhibitors of metalloproteinases TIMP1 and TIMP2 and interleukins IL1- $\alpha$ and IL1- $\beta$ were measured. These factors might be the mediators of bystander effect observed. Furthermore, the ${ }^{125} \mathrm{IUdR}$ that target DNA can be probably released from damaged cells as DNA/radionuclide elements and can irradiate other cells, thus separation of direct and bystander effect is difficult. Summarizing the studies with Auger electrons, Adelstein et al. [56] note that the most radiosensitive cell element is the nuclear DNA where radionuclides induce chromosomal aberrations, and large scale double-strand breaks, which correlate with reproductive survival. They also found that neoplastic transformation and mutagenesis were greatest at low doses with high specific ionization, and that, like in the case of high LET radiation, Auger-electron cascades led to bystander effects.

Alpha particle induced bystander effect. Belyakov et al. [61] using 3-dimentional (3D) model of skin tissue demonstrated that irradiation with microbeam of $\alpha$-particles smaller than one cell size induced apoptosis and micronuclei in bystander cells about $1 \mathrm{~mm}$ away from the irradiated line. Also Sedelnikova et al. [62], found after microbeam irradiation of $3 \mathrm{D}$ artificial tissues of skin or respiratory epithelium the multiple damage in bystander cells, including DNA strand breaks (DSB) visualized as phosphorylated histone H2A (gammaH2AX) foci, generation of micronuclei, apoptosis, senescence and epigenetic changes in DNA methylation. Prior studies [63] on the action of $\alpha$-particles to the cells showed that the DNA damage measured by sister chromatid exchanges (SCE) were caused not only by direct transition of $\alpha$-particle through the cell nucleus, but by forming reactive oxygen species (superoxide radicals and hydrogen peroxide). These factors are believed to be the initiators of the bystander effect (e.g. [11]).

Recently, Fu et al. [64] observed that interaction between a-particle irradiated human bronchial epithelial cells (Beas2B) and its bystander macrophage U937 cells was bilateral. It was observed that irradiated with $1 \mathrm{~Gy}$ a-particles Beas-2B cell induced in bystander U937 cells significant increase of apoptosis and decrease of survival, while bystander U937 macrophages in a feedback loop enhanced apoptosis in a-irradiated Beas-2B epithelial cells almost twice in relation to irradiated epithelial cells without co-culture. This amplification of the detrimental effects of $\alpha$-irradiation including decrease of cell viability and promotion of apoptosis in irradiated cells was connected with activation of nuclear factor kappa B (nuclear factor kappa-light-chain-enhancer, NFkB) and mitogen activated kinases pathways (MAPK) in the bystander U937 cells. However, protective (rescue) bystander effect was also recently found when cancer HeLa cells were exposed to very low dose ( $5 \mathrm{cGy}$ ) of $\alpha$-particles and were coincubated with NIH/3T3 fibroblasts [65]. This rescue effect (diminution of 53BP1foci/cell, the marker of DNA dsb) was also mediated through activation of NF-kB pathway, but in irradiated cells. These all indicate how complex may be bystander effect, and that cell phenotype may be responsible for the divergence. Moreover, the observed bystander signaling between tumor and normal cells may have potential implications in therapeutic outcome of cancer radiotherapy with radionuclides since cancer cells coexist with normal cells like fibroblasts or other.

Dependence of bystander effect on radionuclide location in donor cells. Despite the radiobiological direct responses to Auger-electron emission are particularly sensitive to the site of the decay, not only within the cell but also within the fine structure of chromatin [56], the bystander effects induced by radionuclide seem to be independent of the site of intracellular location in labeled cell. Boyd et al. [66] observed similar killing of bystander HCT116 cells when they were treated with media harvested from either MIBG (accumulating within the cytoplasm) or IUdR (incorporating into DNA) labeled with either ${ }^{131}$ I (low LET $\beta$-emitter), or ${ }^{123}$ I (high LET Auger emitter). An independence of bystander effect generation of radionuclide sub-cellular location was also indicated by Paillas et al. [67] for HCT116 p53-/- and p53+/+ colorectal carcinoma cells. The 
direct effects of ${ }^{125}$ I-labeled monoclonal antibodies targeting the membrane bond, non-internalizing carcinoembryonic antigen (CEA), and internalizing, cytoplasm reaching epidermal growth factor receptor (HER1) were different; anti-CEA ${ }^{125} \mathrm{I}$ $\mathrm{mAbs}$ were much more cytotoxic than anti-HER $1{ }^{125} \mathrm{I}$-mAbs in both p53-/- and p53+/+ HCT116 cells. However, the bystander response of conditioned medium treated cells expressed as gammaH2AX foci (marker of DNA double strand breaks) were similar for CEA and HER1 targeting radionuclides. These indicate that DNA damage is not necessary to generate bystander signaling. Recently, Paillas et al. [68] confirmed that nontargeted response (decrease of survival and DNA double strand breaks) induced by directing 5-[(125)I]iodo-2-deoxyuridine to the nucleus was comparable to that of ${ }^{125} \mathrm{I}-\mathrm{mAb}$ directed against cell surface receptors. Furthermore, they found that targeting the cancer cell surface with ${ }^{125} \mathrm{I}-\mathrm{mAb}$ induces a lipid raft-mediated non-targeted response that compensates for the lower efficacy of non-nuclear targeting.

Dose and dose rate dependence of radionuclide induced bystander effect. The bystander effect is not simply dependent on radiation dose since linear energy transfer (LET) and consequently dose rate is decisive. Boyd et al. [69] compared the induction of bystander effect by gamma rays with that induced by haloanalogs of metaiodobenzylguanidine (MIBG) radiolabeled by isotopes differing in linear-energy-transfer. The ${ }^{131}$ I-MIBG (low- LET $\beta$-emitter), ${ }^{123}$ I-MIBG (potentially high-LET Auger electron emitter), and meta- ${ }^{211}$ At-astatobenzylguanidine ( $\left.{ }^{211} \mathrm{At}-\mathrm{MABG}\right)$, the high-LET $a$-emitter were used to expose two human tumor cell lines, UVW (glioma) and EJ138 (transitional cell carcinoma of the bladder). Cells were previously transfected with the noradrenaline transporter (NAT) gene to enable active uptake of MIBG. Non-irradiated cells were then exposed to medium harvested from cells that accumulated the radiopharmaceuticals or were irradiated with external beam of gamma rays. Whereas gamma irradiation induced bystander effect measured as reduction of clonogenic survival increased with dose delivered to donor cells at lower doses, and saturated over $2 \mathrm{~Gy}$, the low LET $\beta$-emitter ${ }^{131}$ I-MIBG induced bystander cell kill increasing with dose delivered to donors $(0-216 \mu \mathrm{Ci} / \mathrm{ml})$ and was not saturated after treatment with a range of radioactivity causing direct cell death corresponding to external gamma irradiation. However, high LET emitters, ${ }^{123} \mathrm{I}-\mathrm{MIBG}$ (dose for donors $0-216 \mu \mathrm{Ci} / \mathrm{ml}$ ) and ${ }^{211} \mathrm{At}-\mathrm{MABG}$ (dose for donors $0-1.12 \mu \mathrm{Ci} / \mathrm{ml}$ ) induced increasing killing of recipient cells to the levels comparable with that resulted in direct kill of $\sim 65 \%$ and $70 \%$ respectively, then the effect in recipients decreased with increasing activities in donors resulting in U-shape bystander curves. Importantly, neither direct, nor indirect cell kill was observed in cells that did not express the NAT and were incapable of active uptake of MIBG. Again, Boyd et al. [66] found that low LET $\beta$-emitters ${ }^{131} \mathrm{I}$-MIBG or ${ }^{131} \mathrm{I}$-UdR induced bystander cell killing in HCT116 colorectal carcinoma increasing with dose and not saturating after treatment with higher doses, whereas ${ }^{123} \mathrm{I}$ labeled (high LET) both compounds induced U-shaped curves of bystander cell killing. Although this type of relationship, observed only in media transfer experiments are unexplained one can suppose that phenomenon of inverse-dose-rate effect $[70,71]$ took place in presented experiments and low damage was probably induced by the higher dose-rate ${ }^{123} \mathrm{I}$-labeled cells, than by the same dose of lower dose-rate ${ }^{131}$ I-labeled cells. Consequently, bystander signaling was produced less efficiently at higher dose-rate than at lower dose-rate.

Similarly, diverse bystander effects, inhibitory of ${ }^{125} \mathrm{I}$, and stimulatory of ${ }^{123}$ I were also observed in LS174T tumor cells co-culture in vitro [72]. Furthermore, medium from co-culture with ${ }^{125} \mathrm{I}$-labeled cells contained anti-angiogenic factors TIMP1 and TIMP2, and those from co-culture with ${ }^{123}$ I-labeled cells were positive for angiogenin stimulating angiogenesis, indicating engagement of distinct pathways. Contrasting dose-rate dependent bystander effect (damaging or stimulating tumor growth) was observed also in vivo after exposure to ${ }^{123} \mathrm{I}$ or ${ }^{125} \mathrm{I}$ as described below [72], where authors also proposed possible explanation of these discrepancies.

It should be pointed out that hyper-radiosensitivity phenomenon has been observed in external beam irradiated cells (X/gamma rays) in the range of doses below $50 \mathrm{cGy}[73,74]$ and it was connected with bystander effects expressed as reduced survival, and induction of micronuclei. This hyper-radiosensitivity was followed by an increase in radio-resistance at doses between 50 and $100 \mathrm{cGy}$. To explain the low-dose-response it has been proposed that G2-phase cells that survive low-dose radiation exposure experience an overall reduced fidelity of repair [75] and that cells containing residual non-repaired damage are prone to apoptosis [76]. Therefore, we cannot exclude similar phenomenon in radionuclide treated tumors. However, there are only few studies on the hyper-radiosensitivity in the case of radionuclides. Friesen et al. [77] observed that beta irradiation of leukemia cells induced apoptosis with higher efficiency at lowest dose rate applied (i.e., $0.006 \mathrm{~Gy} / \mathrm{min} ; 10 \mathrm{~Gy}$ delivered in $24 \mathrm{~h}$ ) than at higher dose rates. Ren et al. [78] found a biphasic dose-response (0.01-1 Gy), the hyper-radiosensitivity with low dose, followed by resistance at higher dose for micronuclei induction in lymphoblast cells after ${ }^{241} \mathrm{Am}$ external $\alpha$-particles irradiation. Also Raji cells (human lymphoma) irradiated with ${ }^{131}$ I (beta emitter) at very low dose rate $(0.003 \mathrm{~Gy} / \mathrm{min}, 0.38 \mathrm{~Gy})$ showed greater toxicity and apoptosis in comparison with equivalent dose of gamma rays. These events were associated with differential expression of DNA repair genes RAD51 and $P 21$ [79]. These observations indicate that the phenomenon of hyper sensitivity may be present in the radionuclide therapy, but the consequences can be a useful for tumor cells, but may be rather negative to the normal tissues, for example endothelium of blood vessels before they reach the tumor.

\section{In vivo studies of radionuclide bystander effect}

Xue et al. [80] indicated pronounced inhibitory bystander effect in mice on the growth of tumors evoked by human colon LS174T adenocarcinoma cells injected concomitantly 
with cells pre-labeled with lethal doses of DNA-incorporated ${ }^{125} \mathrm{IUdR}$. Since electrons emitted by the decaying ${ }^{125} \mathrm{I}$ bound to DNA have a subcellular range $(<0.5 \mu \mathrm{m})$, the direct irradiation of unlabeled cells is minimal, thus bystander effect had to be exerted by factors generated in, and secreted by ${ }^{125} \mathrm{IUdR}$ labeled cells, although release of DNA/ ${ }^{125} \mathrm{IUdR}$ products from killed cells may probably cause direct irradiation of previously non-targeted cells.

Bystander effect induced by radionuclides in vivo can be both damaging and stimulating, just as in the case observed in in vitro studies. Kishikawa et al. [72] observed that human LS174T adenocarcinoma cells lethally damaged by ${ }^{123} \mathrm{I}$ $\left({ }^{123} \mathrm{IUdR}\right)$, an Auger electron emitter injected subcutaneously to nude mice as a mixture with unlabeled cells enhanced significantly the growth of tumors induced. In contrast, an Auger electron emitter ${ }^{125}$ I whose electron spectrum is identical to that of ${ }^{123}$ I significantly inhibited tumor growth when the same proportions of labelled: unlabeled cells were used. Although both isotopes emit Auger electrons, they differ in physical half-lives ( ${ }^{123} \mathrm{I}, T 1 / 2=13.3 \mathrm{~h}$, and ${ }^{125} \mathrm{I}, T 1 / 2=60.5$ days), and consequently they differ in the dose rate, which is 109 times higher for ${ }^{123}$-labeled cells than for ${ }^{125}$ I-labeled cells. Moreover, number of decays/cell after incubation in vivo with ${ }^{125} \mathrm{IUdR}$ is about twice of that calculated for ${ }^{123} \mathrm{IUdR}$ [72]. These all suggest that bystander effects should be estimated for different radionuclides at different doses before drawing out conclusion with regard bystander effect phenomenon.

The bystander effect was also observed in A431 tumor xenografts injected with anti-CEA ${ }^{125} \mathrm{I}-\mathrm{mAbs}$. Despite radioactivity was mainly localized at the periphery of tumors, DNA DSBs were homogenously distributed throughout the tumor, as indicated by immunofluorescence detection of p53-binding protein 1 (53BP1), a sensor of DNA damage [68].

${ }^{131}$ Iodine, a $\beta$-emitter is used as ${ }^{131}$ I-MIBG, a potential therapeutic, as well as imaging agent in neuroblastoma [80], or as sodium iodide $\left({ }^{131} \mathrm{I}-\mathrm{NaI}\right)$ operating via sodium iodide symporter (NIS) for treatment of well-differentiated thyroid carcinoma [81]. Other types of cancer expressing NIS could be also effectively treated with ${ }^{131} \mathrm{I}$ [82]. Mitrofanova et al. [83] documented a strong growth inhibition of human prostate xenografts engendered by DU145 cells transduced with human NIS gene. Low dose of ${ }^{131} \mathrm{I}-\mathrm{NaI}(1 \mathrm{mCi})$ inhibited growth of relatively large tumors $\left(\sim 800 \mathrm{~mm}^{3}\right)$. Since not all cells were efficiently transduced with NIS, the observed tumor growth inhibition had to be caused via bystander effects. Based on 3-D spheroids, authors calculated that the NIS allowed to reduce the injected radioiodine dose by $70 \%$ with the same antitumor efficacy as by much higher dose in non-transduced tumors. This suggests that modulation of bystander effect might be probably possible in human tumor radionuclide therapy via transgene (NIS, NAT) delivery by tumor specific elements.

Astatine-211 $\left({ }^{211} \mathrm{At}\right)$, an alpha particle emitting halogen was used to study an influence of radiation-induced biological effects in the thyroid tissue in BALB/c nude mice [84]. The linear energy transfer of alpha particles allows preferentially damage the cellular DNA, inducing double strand breaks. The gene expression profiles were used as the endpoint in experiment. Mice were intravenously injected with $0.064-42 \mathrm{kBq}$ of ${ }^{211} \mathrm{At}$, resulting in absorbed doses of 0.05 to $32 \mathrm{~Gy}$ in the thyroid gland. Distinctive gene expression profiles compared to non-irradiated controls were found in thyroid tissue exposed to different absorbed doses $(0.05,0.5$, $1.4,11$, or $32 \mathrm{~Gy}$ ). Interestingly larger number of genes were affected at low absorbed doses ( 0.05 and $0.5 \mathrm{~Gy}$ ) compared to intermediate (1.4 Gy) and higher absorbed doses (11 and 32 Gy). The affected genes play an important role in cellular metabolism, transport and communication, DNA, RNA and protein processing, immune response, apoptosis, cellular maintenance, and cell development. Furthermore, downregulation was predominantly observed at lower absorbed doses $(0.05$ and $0.5 \mathrm{~Gy})$, and up-regulation at higher absorbed doses (11 and $32 \mathrm{~Gy}$ ). Since irradiation at low absorbed doses induced changes in larger number of gene expression, authors suggest that this inverse response originates partly from non-irradiated cells in the tissue, i.e., bystander cells [84]. Thus, the response acquired at high absorbed doses cannot be extrapolated down to low absorbed doses and vice versa, especially that the hypersensitivity effects at low dose-rate $(0.1-1.0 \mathrm{~Gy} / \mathrm{h})$ have been documented as a decrease of cell survival after 1.5-5 Gy [85]. This should be kept in mind when radionuclide bystander effect in clinical practice is considered. Although there are some differences between radionuclide (high LET) and external beam (low LET) irradiation induced bystander effects there are also many similarities between radionuclide-induced and external beaminduced bystander effects. The concise comparison of external beam induced non-targeted effects with those induced by radionuclide decay is presented in Table 1.

\section{Clinical look at bystander effect induced by radionuclides}

Cognition the mechanisms of bystander effect induced during radionuclide therapy would allow the better understanding of the potential benefits or risks associated with this therapy. Currently applied clinical radionuclide therapy uses different types of radionuclides, recently discussed in relation to their advantages and disadvantages by Kumar et al. [86 ]. Sgouros et al. [87] summarizes the clinical trials using a-particle emitters. They include ${ }^{211}$ At-labeled antitenascin and IgG applied in glioblastoma multiforme, ${ }^{213} \mathrm{Bi}$-labeled anti-CD33 IgG in myelogenous leukemia (acute or chronic), ${ }^{213} \mathrm{Bi}$-antineurokinin receptor peptide in glioblastoma, ${ }^{213} \mathrm{Bi}$ labeled specific IgG in melanoma and ${ }^{223} \mathrm{Ra}$-dichloride in skeletal breast and prostate cancer metastases. The use of radioimmunotherapy with highly toxic $\alpha$-particles involves the risk of damage to normal cells due to nonspecific hit by radiolabeled agents present in solution, therefore microdosimetry is most needed. Chouin et al. [88] applied a microdosimetric model to analyze the results of experimental studies on two lymphoid cell lines (T2 and Ada) exposed 
Table 1. Brief comparison of non-targeted effects induced by external beam irradiation and by radionuclides. Based on reviews [1-4, 13] and currently presented papers.

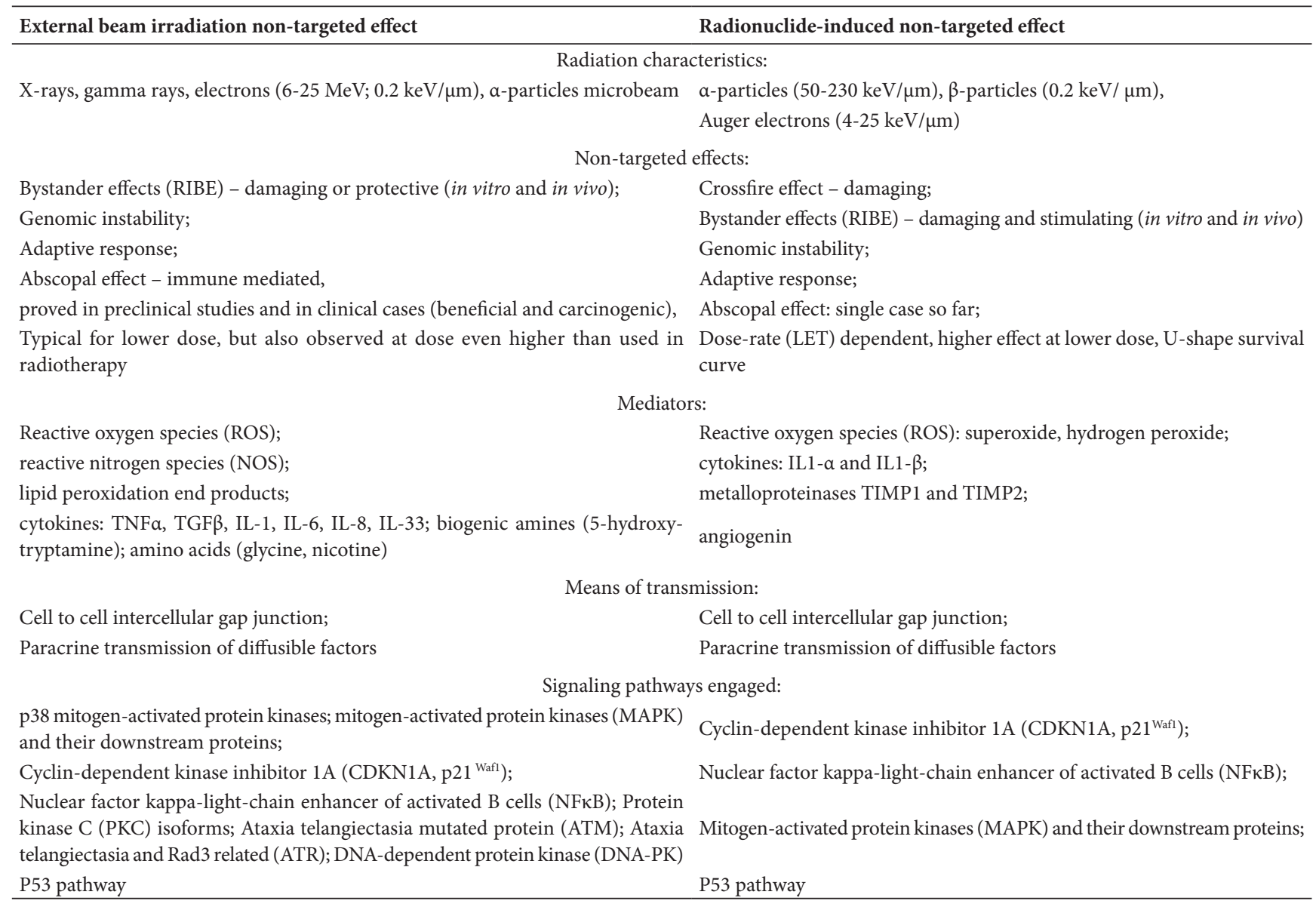

to ${ }^{213} \mathrm{Bi}$-radiolabeled antibodies. The ${ }^{213} \mathrm{Bi}$ is mainly short-lived beta emitter with only $2 \%$ alpha particle emission. Using monoclonal antibodies that target the $\mathrm{MHC} /$ peptide complex it is possible to modulate the density of targeted antigens by varying the concentration of the antibodies loaded onto the cells. This provides the ability to change the ratio of specific irradiation (cell-bound antibodies) to nonspecific (antibodies that remain in solution). The authors observed an excessive mortality of both cell types with respect to the percentage of hit cells at low mean absorbed doses $(0,001-0,1 \mathrm{~Gy})$ indicating a high incidence of a bystander effect [89]. Alpha particles are highly damaging to DNA $[61,62]$, but formation of ROS (superoxide and hydrogen peroxide), the known mediators of bystander effect was documented [63]. The presence of bystander effect at low absorbed doses when direct killing effect is low can be beneficial for tumor treatment, although it can result in damage of healthy cells especially when applied in lymphoid cancer.

When solid tumor cell populations are exposed to low dose a-particle radiation, not all cells will be traversed by a radiation track. However, stressful effects occur in both irradiated and bystander cells in the population. The distribution of radionuclide within solid tumor cell population is not homogenous because of non-homogenous vascular network, presence of cluster of necrosis, different interstitial fluid pressure, and variable expression of particular antigens/receptors, therefore bystander effect may have a large role to play in destroying tumors. These limitations also occur in application of other types of radionuclides. Although it is yet practically impossible to distinguish direct effects of radionuclide radiation from those caused by signals released by the radio-labeled cells, all in vitro studies indicate without any doubt that $\alpha$-particles generate bystander signaling which usually lead to elevation of damage and genomic instability at relatively low doses (cGy) [7, 61, 62, 89]. Gaillard et al. [90] estimated the propagation distance of the $\alpha$-particle-induced bystander effect in AG1522 normal human skin fibroblasts in the range from 20 to $40 \mu \mathrm{m}$, which corresponds to a set of $\sim 3-4$ cell diameters. The critical contributor to propagation of this stressful effect measured by expression of stress responsive protein $\mathrm{p} 21^{\text {Wafl }}$ (also known as CDKN1A) in bystander cells was DNA damage caused by nuclear traversal and intercellular communication via gap 
junctions. Gap junctions however, are not a prerequisite of bystander effect signaling and this was confirmed in many experiments with radiation conditioned medium [reviewed in 1-5]. Cell-to cell communication plays a role in response to different type of stressors not only in mammal cells but also in bacterial population as presented by Belyaev group for electromagnetic field [91, 92], and for low (cGys) doses of X-rays [93] and gamma rays [94] where effect measured as chromatin viscosity changed on dependence of cell density. Based on the observed cell density dependent effects, authors supposed that the mediators of intercellular communication are some chemical messengers or secondary radiation.

For clinical purposes Mairs and Boyd [33] proposed alternative use of alpha emitting astatine At-211 [ $\left.{ }^{211} \mathrm{At}\right] \mathrm{MABG}$ instead beta-particle emitter [ $\left.{ }^{131} \mathrm{I}\right] \mathrm{MIBG}$, commonly used in radionuclide therapy of neuroendocrine tumors. Experiments performed by those authors on cellular spheroids showed that substitution of I-131 by At-211 is 1000-time more cytotoxic on concentration level. Moreover, the short range of alpha particle (less than $80 \mu \mathrm{m}$ ) although limits a crossfire action, efficiently generates bystander effect in NET expressing tumor cells. These indicate the therapeutic capacity of smaller proportion of $\left[{ }^{211} \mathrm{At}\right] \mathrm{MABG}$ targeted tumor cells to kill neighbor non-targeted cells via bystandermediated signaling.

The important concern related to the bystander effect is addressing the possible genomic instability that may be induced in radionuclide therapy. Studies of Kadim et al. [95] indicate that low dose of $\alpha$-particles induced delayed chromosomal aberrations in bystander human lymphocytes when fractions of the population were irradiated at G0/G1 of the cell cycle, with precisely one ${ }^{3} \mathrm{He}^{2+}$ particle $(105 \mathrm{KeV} /$ $\mu \mathrm{m})$ delivered through the center of each nucleus. Interestingly, substantial heterogeneity in bystander cell genomic instability between donors of lymphocytes was observed. On the other hand, Hu et al. [96] found no significant elevation of inheritable interchromosomal aberrations in the offspring of bystander primary human fibroblast after $\alpha$-particle irradiation, although the frequencies of chromatid breaks in bystander cells significantly increased.

Preclinical studies and clinical cases document a systemic bystander effect known as "out of field" or "abscopal effect" after external beam radiotherapy. The terms commonly refer to distant tumor regression after localized irradiation [97]. Abscopal effects were observed in different tumor types after conventional radiotherapy, as well after stereotactic ablative radiotherapy almost always combined with immunotherapy which act synergistically (reviewed by [13]). The mechanism of this synergy is based on reduction by radiation of immunosuppression and tolerance of tumor by microenvironment of the body, followed by induction of immune response $[98,99]$. Radiation-induced damage in such structures like double-stranded DNA, RNA, chromatin, or high-mobility group protein 1 (HMGB-1) generally described as damageassociated molecular patterns (DAMPs) which are recognized by Toll-like receptors (TLR) on immune competent cells e.g. macrophages or dendritic cells lead to immune mediated killing of neoplastic cells even in areas distant from irradiation field $[100,101]$. A key role of macrophages in the secondary bystander effect at least after photon irradiation was documented [102]. The schematic illustration of the immune mediated abscopal effect induced by external beam ionizing radiation is presentedin Figure 1. It may be assumed that in targeted radionuclide therapy an abscopal effect can also take place since radiation from radionuclides damaging the tumor cells may induce immune response, particularly because radionuclide therapy is based on low dose/low doserate. The activation of immune system after low dose total body irradiation is commonly observed [18 and references therein]. Recently published the clinical case report supports the assumption that abscopal effect may appear in radionuclide therapy. Ghodadra et al. [103] presented for the first time the abscopal effect observed in patient with lung cancer after radioembolization with Yttrium-90 ( $\beta$-emitter) of hepatic metastases. The patient was treated with external beam radiation to lung tumor followed by systemic chemotherapy with carboplatin, paclitaxel, docetaxel, and gemcitabine for 18 months. However, subsequently metastases to three segments of liver progressed, with the greatest to right lobe. Radioembolization performed via the right hepatic artery with a dose of $1.24 \mathrm{GBq}$ aimed to radiation distribution for disease in the right lobe caused not only regression of treated metastases, but complete regression of the non-targeted, left hepatic lobe lesion. The mechanism of radionuclide induced abscopal effect, as in the case of external radiotherapy is modulated immunologically. Similar mechanism might operate in external beam and radionuclide radiotherapy. Authors propose that radionuclide causes locally the tumor cell death by apoptosis and necrosis. Damaged tumor cells release tumor-associated antigens (TAAs), chemokines (MCP-1 and CXCL16) which attract antigen presenting cells (APCs), cytokines (like TNF-a, IL-1, IL-16), "danger signals" (HMGB1, adenosine triphosphate-ATP, and calreticulin-CRT) as well. Moreover, tumor cells also cause overregulation of cell adhesion molecules, MHC I/II, and Fas. Subsequently, circulating dendritic cells (DCs) transfer the TAAs to tumor-draining lymph nodes and present them to naive CD4 and CD8 T lymphocytes causing their activation via interaction of receptors on T cells with peptide/MHC complexes on DCs. Activated CD4 and CD8 T cells proliferate and differentiate into effectors CD4+ T cells and cytotoxic T cells (CTLs) respectively, becoming able to target non-treated tumor cells (Figure2). It is hoped that radioembolization with as high doses of Y-90 as 200-300 Gy and even 3000 Gy [104] as palliative therapy can induce stimulation of the immune system, and subsequently abscopal effect. Combining radionuclide therapy with immunotherapy e.g., ipilimumab, GM-CSF or IL-2, presents additional opportunities to augment Y-90 antitumor effect.

In conclusion, in vitro studies and preclinical experiments allow saying that non-targeted effects created by 


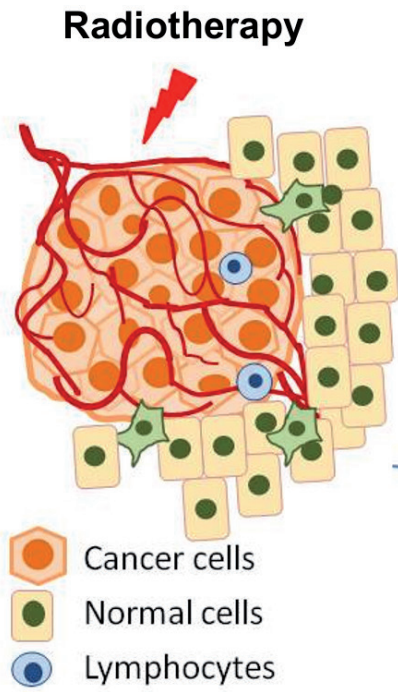

Series of events initiated by ionizing radiation (ROS, RNS, NO, TGF $\beta$, IL6, IL 8 , cell death, apoptosis, necrosis, senescence

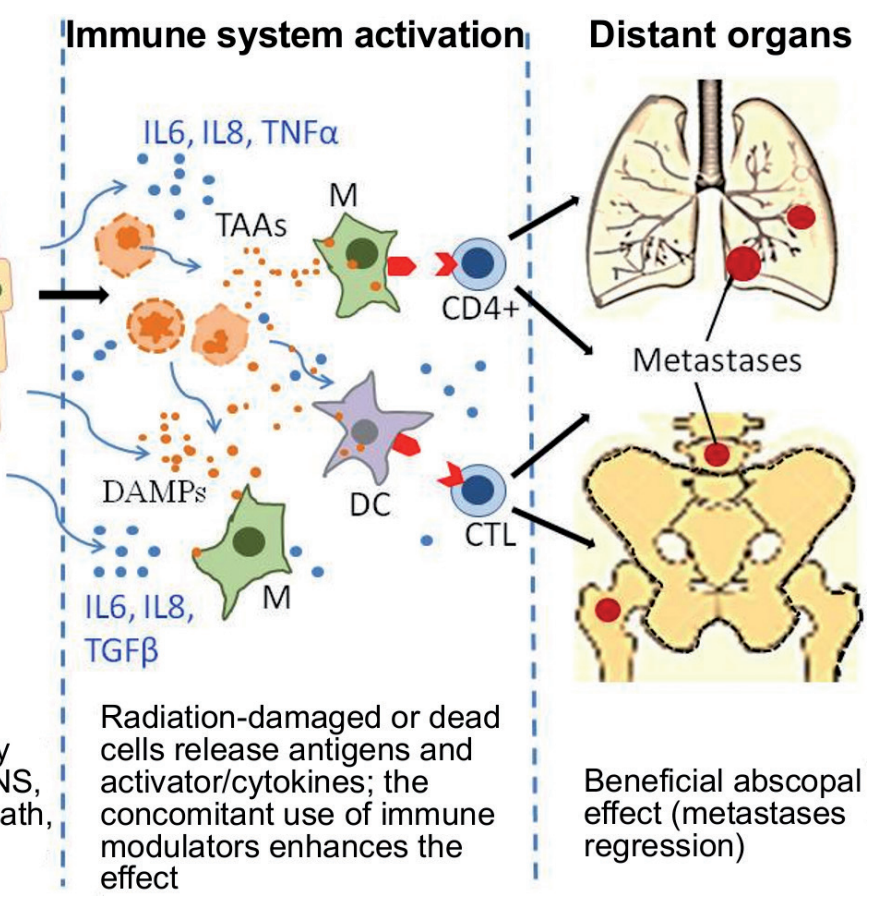

Figure 1. Diagram ilustrating the immune mediated abscopal effect induced by external beam ionizing radiation. Radiation of tumor (e.g. primary tumor) induces series of events like oxidative stress leading to cell damage, apoptosis, necrosis, senescence and cytokine production. Damaged or dead cells release tumor associated antigens (TAAs) and damage-associated molecular patterns (DAMPs), leading to maturation of antigen-presenting cells like macrophages (M) and dendritic cells (DC), which activate effector immune cells, CD4+ lymphocytes and CD8+ cytotoxic T lymphocytes (CTL). Activated immune cells became able to destroy distant metastases.

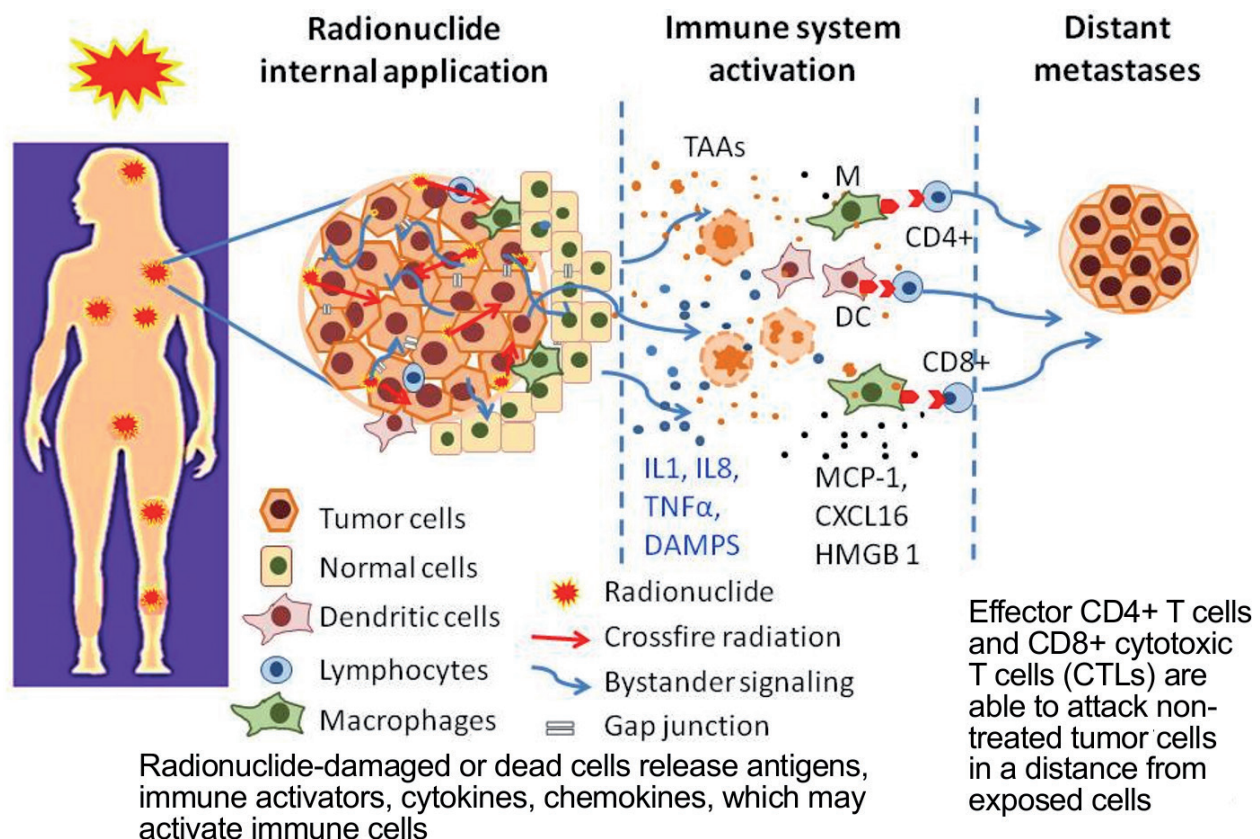

Figure 2. Schematic illustration of non-targeted effects induced by internal uptake of radionuclides (radionuclide-labeled monoclonal antibodies or other carriers), which specifically target tumor cells. Damaged or killed cells due to direct absorbtion of radiation energy or crossfire effect release tumor associated antigens (TAAs) and damage-associated molecular patterns (DAMPs), leading to maturation of antigen-presenting cells like macrophages (M) and dendritic cells (DC), which activate effector immune cells, CD4+ lymphocytes and CD8+ cytotoxic T lymphocytes (CTL). Activated immune cells became able to destroy distant cells, which have not been reached by the radionuclides. 
targeted radionuclides appear distinct from external beam irradiation and are characterized by dose-rate and LET dependence often showing inverse dose-rate relationship and $U$-shaped survival curves. The radiobiology of targeted radionuclide therapy needs to be further explored to gain the knowledge about bystander effect, which could possibly lead to development of appropriate recommendations and protocols, which could even change the existing concept of radionuclide therapy. This challenge comprises the determination of the best dose and dose-rate effects for different type radionuclides and for particular types of tumors to selectively achieve detrimental effects towards tumor cells while preserve healthy tissues. The separation of the direct effect of radionuclide decay from crossfire and bystander effects in clinical targeted radionuclide therapy is yet impossible, thus we are forced to rely on conclusions drawn from 3-D culture model and animal studies. It can be expected that comparative analysis of results of clinical treatment of the same tumor types by different radionuclides, and at different doses/dose-rate would allow finding some beneficial or negative impact of radionuclide induced bystander effect. It appears that the beneficial effect will prevail, due to radionuclide selectively targeting the tumor cells and due to a short duration exposure of healthy cells to radiation while delivery to tumor and elimination from the body. Isolated so far report demonstrating that under specific circumstances it is possible to obtain a beneficial abscopal effect confirms that radionuclide therapy may be associated with non-targeted bystander effect. For the time being we must be aware that in addition to direct toxic effects of radionuclide radiation to targeted cells the bystander effects in non-exposed neighbor cells occur, which probably enhances this absorbed doseeffect within a tumor, although, it cannot be ruled out that healthy cells can also be exposed.

Acknowledgments: This work was supported by the grant DEC2012/04/A/ST7/00353 from the National Center of Science (Poland).

\section{References}

[1] RZESZOWSKA-WOLNY J, PRZYBYSZEWSKI WM, WIDEL $M$. Ionizing radiation-induced bystander effects, potential targets for modulation of radiotherapy. Eur J Pharmacol 2009; 625: 156-164. https://doi.org/10.1016/j. ejphar.2009.07.028

[2] PRISE KM, O'SULLIVAN JM. Radiation-induced bystander signaling in cancer therapy. Nat Rev Cancer 2009; 9: 351-360. https://doi.org/10.1038/nrc2603

[3] WIDE€ M, PRZYBYSZEWSKI W, RZESZOWSKA-WOLNY J Radiation-induced bystander effect: the important part of ionizing radiation response. Potential clinical implications. Postepy Hig Med Dosw (Online) 2009; 63: 377-388.

[4] MARIN A, MARTIN M, LINAN O, ALVARENGA F, LOPEZ $\mathrm{M}$ et al. Bystander effects and radiotherapy. Rep Pract Oncol Radiother 2014; 20: 12-21. https://doi.org/10.1016/j. rpor.2014.08.004
[5] MOTHERSILL C, SEYMOUR CB. Medium from irradiated human epithelial cells but not human fibroblasts reduces the clonogenic survival of unirradiated cells. Int J Radiat Biol 1997; 71, 421-427. https://doi.org/10.1080/095530097144030

[6] POLESZCZUK J, KRZYWON A, FORYS U. WIDEL M. Connecting radiation-induced bystander effects and senescence to improve radiation response prediction. Radiat Res 2015; 183: 571-577. https://doi.org/10.1667/RR13907.1

[7] NAGASAWA M, LITTLE JB. Induction of sister chromatid exchanges by extremely low doses of alpha-particles. Cancer Res 1992; 52: 639-6396.

[8] LEHNERT BE, GOODWIN EH, DESHPANDE A. Extracellular factor(s) following exposure to alpha particles can cause sister chromatid exchanges in normal human cells. Cancer Res 1997; 57: 2164-2171.

[9] PRISE KM, BELYAKOV OV, FOLKARD M and MICHAEL BD Studies of bystander effects in human fibroblasts using a charged particle microbeam. Int J Radiat Biol 1998; 74: 793-798. https://doi.org/10.1080/095530098141087

[10] PRZYBYSZEWSKI WM, WIDEL M, SZURKO A, LUBECKA B, MATULEWICZ L et al. Multiple bystander effect of irradiated megacolonies of melanoma cells on non-irradiated neighbors. Cancer Lett 2004; 214: 91-102. https://doi. org/10.1016/j.canlet.2004.03.046

[11] WIDEL M, PRZYBYSZEWSKI WM, CIESLAR-POBUDA A, SAENKO YV, RZESZOWSKA-WOLNY J. Bystander normal human fibroblasts reduce damage response in radiation targeted cancer cells through intercellular ROS level modulation. Mutat Res 2012; 731: 117-124. https://doi.org/10.1016/j. mrfmmm.2011.12.007

[12] WIDEL M, LALIK A, KRZYWON A, POLESZCZUK J, FUJAREWICZ $\mathrm{K}$ et al. The different radiation response and radiation-induced bystander effects in colorectal carcinoma cells differing in p53 status. Mutat Res 2015; 778: 61-70. https://doi.org/10.1016/j.mrfmmm.2015.06.003

[13] WIDEL M. Radiation induced bystander effect: from in vitro studies to clinical application. Int J Med Phys Clin Engin and Radiat Oncol (IJMPCERO) online. 2016; 5: 1-17. DOI: 10.4236/ijmpcero.2016.51001 https://doi.org/10.4236/ijmpcero.2016.51001

[14] MORGAN WF. Non-targeted and delayed effects of exposure to ionizing radiation: II. Radiation-induced genomic instability and bystander effects in vivo, clastogenic factors and transgenerational effects. Radiat Res 2003; 159: 581-596. https://doi.org/10.1667/0033-7587(2003)159[0581:NADEO E]2.0.CO;2

[15] IYER R, LEHNERT BE. Low Dose, Low-LET ionizing radiation-induced radioadaptation and associated early responses in unirradiated cells. Mutat Res 2002; 503: 1-9. https://doi. org/10.1016/S0027-5107(02)00068-4

[16] WIDEL M, SZURKO A, PRZYBYSZEWSKI W, LANUSZEWSKA J Non-irradiated bystander fibroblasts attenuate damage to irradiated cancer cells. Radioprotection 2008; 43: 158. DOI: https://doi.org/10.1051/radiopro:2008620

[17] CHEN S, ZHAO Y, CHIU SK, ZHU L, WU L et al. Rescue effects in radiobiology: Unirradiated bystander cells assist irradiated cells through intercellular signal feedback. 
Mutat Res 2011; 706: 59-64. https://doi.org/10.1016/j. mrfmmm.2010.10.011

[18] SGOUROS G, KNOX SJ, JOINER MC, MORGAN WF, KASSIS AI. MIRD continuing education: Bystander and lowdose-rate effects: are these relevant to radionuclide therapy? J Nucl Med 2007; 48: 1683-1691. https://doi.org/10.2967/ jnumed.105.028183

[19] BRADY D, O'SULLIVAN JM, PRISE KM. What is the role of the bystander response in radionuclide therapies? Front Oncol 2013; 3: 215. https://doi.org/10.3389/ fonc.2013.00215

[20] POUGET JP, LOZZA C, DESHAYES E, BOUDOUSQ V, NAVARRO-TEULON I. Introduction to radiobiology of targeted radionuclide therapy. Front Med (Lausanne) 2015; 2: 12. https://doi.org/10.3389/fmed.2015.00012

[21] DASH A, KNAPP FF, PILLAI MR. Targeted radionuclide therapy-an overview. Curr Radiopharm 2013; 6: 152-180. https://doi.org/10.2174/18744710113066660023

[22] KAWASHIMA H. Radioimmunotherapy: A specific treatment protocol for cancer by cytotoxic radioisotopes conjugated to antibodies. ScientificWorldJournal 2014; 2014: 492061. https:// doi.org/10.1155/2014/492061

[23] BLOY N, POL J, MANIC G, VITALE I, EGGERMONT A et al. Trial Watch: Radioimmunotherapy for oncological indications. OncoImmunology 2014; 3: e954929. https://doi.org/10 $.4161 / 21624011.2014 .954929$

[24] WITZIG TE, GORDON LI, FERNANDO C, CZUCZMAN MS, EMMANOUILIDES C. Randomized controlled trial of yttrium-90-labeled ibritumomab tiuxetan radioimmunotherapy versus rituximab immunotherapy for patients with relapsed or refractory low-grade, follicular, or transformed b-cell non-Hodgkin's lymphoma. J Clin Oncol 2002; 20: 2453-2463. https://doi.org/10.1200//CO.2002.11.076

[25] HORNING SJ, YOUNES A, JAIN V, KROLL S, LUCAS J et al. Efficacy and safety of tositumomab and iodine-131tositumomab (Bexxar) in B-cell lymphoma, progressive after rituximab. J Clin Oncol 2005; 23: 712-719. https://doi.org/10.1200/ $\underline{\mathrm{LCO} .2005 .07 .040}$

[26] JURCZAK W., Szostak M., Jakobczyk M, Sowa-Staszczak A, ZIMOWSKA-CURYŁO D et al. Hematological toxicity of radioimmunotherpy with 90Y Ibritumomab. Przegl Lek 2012; 69: 107-114.

[27] DENARDO GL, SCHLOM J, BUCHSBAUM DJ, MEREDITH RF, O'DONOGHUE JA et al. Rationales, evidence, and design considerations for fractionated radioimmunotherapy. Cancer 2002; 94: 1332-1348. https://doi.org/10.1002/cncr.10304

[28] BRANS B, LINDEN O, GIAMMARILE F, TENNVALL J, PUNT C. Clinical applications of newer radionuclide therapies. Eur J Cancer 2006; 42: 994-1003. https://doi. org/10.1016/j.ejca.2005.12.020

[29] BRADY D, PARKER CC, O‘SULLIVAN JM. Bone-targeting radiopharmaceuticals including radium-223. Cancer J 2013; 19: 71-78. https://doi.org/10.1097/PPO.0b013e318282479b

[30] GAZE MN, WHELDON TE. Radiolabelled mIBG in the treatment of neuroblastoma. Eur J Cancer 1996; 32A: 93-96.

[31] TRONCONE L, RUFINI V. 131I-MIBG therapy of neural crest tumours (review). Anticancer Res 1997; 17: 1823-1831.
[32] MUKHERJEE JJ, KALTSAS GA, ISLAM N, PLOWMAN PN, FOLEY R et al. Treatment of metastatic carcinoid tumours, phaeochromocytoma, paraganglioma and medullary carcinoma of the thyroid with 131I-meta-iodobenzylguanidine ([131I]MIBG). Clin Endocrinol (Oxf) 2001; 55: 47-60. https:// doi.org/10.1046/j.1365-2265.2001.01309.x

[33] MAIRS RJ, BOYD M. Preclinical assessment of strategies for enhancement of metaiodobenzylguanidine therapy of neuroendocrine tumors. Semin Nucl Med 2011; 41:334-344. https://doi.org/10.1053/j.semnuclmed.2011.03.004

[34] FULLERTON NE, BOYD M, MAIRS RJ, KEITH WN, ALDERWISH $\mathrm{O}$ et al. Combining a targeted radiotherapy and gene therapy approach for adenocarcinoma of prostate. Prostate Cancer Prostatic Dis 2004; 7: 355-363. https://doi. org/10.1038/sj.pcan.4500760

[35] NILSSON S, LARSEN RH, FOSS SD, BALTESKARD L, BORCH KW et al. First clinical experience with a-emitting radium-223 in the treatment of skeletal metastases. Clin Cancer Res 2005; 11; 4451-4459. https://doi.org/10.1158/1078-0432. CCR-04-2244

[36] EVAN S, HORTON R. Radium-223 dichloride: a novel treatment option for castration-resistant prostate cancer patients with symptomatic bone metastases. Ann Pharmacother 2015; 49: 469-476. https://doi.org/10.1177/1060028014565444

[37] BAACZYK M, MILECKI P, BAACZYK E, SOWINSKI J. The effectiveness of strontium 89 in the treatment of pain caused by bone metastases in patients with prostate cancer. Polska Medycyna Paliatywna 2003; 2: 141-146.

[38] KASSIS IA, ADELSTEIN SJ. Radiobiologic principles of radionuclide therapy. J Nucl Med 2005; 46: 4S-12S.

[39] FENDLER WP, VENTER V, STIEF CG, GRATZKE C, BARTENSTEIN P. Nuclearmedizinische Therapie und Diagnostic in der Urologie. Der Urologe 2015; 7: 1025-1035. https://doi. org/10.1007/s00120-014-3730-y

[40] BAUM RP, HELLWIG D, MEZZETTI M. Position of nuclear medicine modalities in the diagnostic workup of cancer patients: lung cancer. Q J Nucl Med Mol Imaging 2004; 48: 119-142.

[41] KUMAR C, SHETAKE N, DESAI S, KUMAR A, SAMUEL $\mathrm{G}$ et al. Relevance of radiobiological concepts in radionuclide therapy of cancer. Int J Radiat Biol 2016; 92: 173-186. https:// doi.org/10.3109/09553002.2016.1144944

[42] GERASHCHENKO BI, HOWELL RW. Proliferative response of bystander cells adjacent to cells with incorporated radioactivity. Cytometry A 2004; 60: 155-164.

[43] PAINTER RB, DREW RM, HUGHES WL Inhibition of HeLa growth by intranuclear tritium. Science 1958; 127: 1244-1245. https://doi.org/10.1126/science.127.3308.1244

[44] DREW RM, PAINTER RB. Action of tritiated thymidine on the clonal growth of mammalian cells. Radiat Res 1959; 11: 535-544. https://doi.org/10.2307/3570807

[45] BEDFORD JS, MITCHELL JB, GRIGGS HG, BENDER MA. Cell killing by gamma rays and beta particles from tritiated water and incorporated tritiated thymidine. Radiat Res 1975; 63: 531-543. https://doi.org/10.2307/3574104

[46] DEWEY WC, SEDITA BA, HUMPHREY RM. Chromosomal aberrations induced by tritiated thymidine from tritiated water 
and incorporated tritiated thymidine. Radiat Res 1975; 63: 531-543. https://doi.org/10.2307/3574104

[47] HORI TA, NAKAI S. Unusual dose-response of chromosome aberrations induced in human by very low dose exposures to tritium. Mutat Res 1978; 50: 101-110. https:// doi.org/10.1016/0027-5107(78)90065-9

[48] CLEAVER JE, THOMAS GH, BURKI HJ. Biological damage from intranuclear tritium: DNA strand breaks and their repair. Science 1972; 177: 996-998. https://doi.org/10.1126/ science.177.4053.996

[49] POLLACK A, BAGWELL CB, IRVIN GL. Radiation from tritiated thymidine perturbs the cell cycle progression of stimulated lymphocytes. Science 1979; 203: 1025-1027. https://doi.org/10.1126/science.424727

[50] BISHAYEE A, RAO DV, HOWELL RW. Evidence for pronounced bystander effects caused by nonuniform of radioactivity distributions using a novel three-dimensional tissue culture model. Radiat Res 1999; 152: 88-97. https:// doi.org/10.2307/3580054

[51] BISHAYEE A, HILL HZ, STEIN D, RAO DV, Howell RW. Free radical-initiated and gap junction-mediated bystander effect due to nonuniform distribution of incorporated radioactivity in a three-dimensional tissue culture model. Radiat Res 2001; 155: 335-344. https://doi.org/10.1667/00337587(2001)155[0335:FRIAG]]2.0.CO;2

[52] PINTO M, AZZAM EI, HOWELL RW. Bystander responses in three-dimensional cultures containing radiolabelled and unlabelled human cells. Radiat Prot Dosimetry 2006; 122: 252-255. https://doi.org/10.1093/rpd/ncl460

[53] PINTO M, AZZAM EI, HOWELL RW. Investigation of adaptive responses in bystander cells in $3 \mathrm{D}$ cultures containing tritium-labeled and unlabeled normal human fibroblasts. Radiat Res 2010; 174: 216-227. https://doi.org/10.1667/ RR1866.1

[54] PERSAUD R, ZHOU H, BAKER SE, HEI TK, HALL EJ. Assessment of low linear energy transfer radiationinduced bystander mutagenesis in a three-dimensional culture model. Cancer Res 2005; 65: 9876-9882. https://doi. org/10.1158/0008-5472.CAN-04-2875

[55] PERSAUD R, ZHOU H, HEI TK, HALL EJ. Demonstration of a radiation-induced bystander effect for low dose low LET beta-particles. Radiat Environ Biophys 2007; 46: 395-400. https://doi.org/10.1007/s00411-007-0116-1

[56] ADELSTEIN SJ, KASSIS AI, BODEI L, MARIANI G. Radiotoxicity of iodine-125 and other auger-electron-emitting radionuclides: background to therapy. Cancer Biother Radiopharm 2003; 18: 301-316. https://doi. org/10.1089/108497803322285062

[57] HOWELL RW, BISHAYEE A. Bystander effects caused by nonuniform distributions of DNA-incorporated $125 \mathrm{I}$. Micron 2002; 33: 127-132. https://doi.org/10.1016/S09684328(01)00007-5

[58] KASSIS AI. Molecular and cellular radiobiological effects of Auger emitting radionuclides. Radiat Prot Dosimetry 2011; 143: 241-247. https://doi.org/10.1093/rpd/ncq385

[59] AKUDUGU JM, AZZAM EI, HOWELL RW. Induction of lethal bystander effects in human breast cancer cell cultures by DNA-incorporated Iodine-125 depends on phenotype. Int J Radiat Biol 2012; 88: 1028-1038. https://doi.org/10.3109/09 $\underline{553002.2012 .683511}$

[60] MAMLOUK O, BALAGURUMOORTHY P, WANG K, ADELSTEIN SJ, KASSIS AI. Bystander effect in tumor cells produced by Iodine-125 labeled human lymphocytes. Int J Radiat Biol 2012; 88: 1019-1027. https://doi.org/10.3109/09 $\underline{553002.2012 .702297}$

[61] BELYAKOV OV, MITCHELL SA, PARIKH D, RANDERSPEHRSON G, MARINO SA et al. Biological effects in unirradiated human tissue induced by radiation damage up to $1 \mathrm{~mm}$ away. Proc Natl Acad Sci U S A 2005; 102: 14203-14208. https://doi.org/10.1073/pnas.0505020102

[62] SEDELNIKOVA OA, NAKAMURA A, KOVALCHUK O, KOTURBASH I, MITCHELL SA et al. DNA double-strand breaks form in bystander cells after microbeam irradiation of three-dimensional human tissue models. Cancer Res 2007; 67: 4295-4302. https://doi.org/10.1158/0008-5472.CAN-06-4442

[63] Narayanan PK, Goodwin EH, Lehnert BE Alpha particles initiate biological production of superoxide anions and hydrogen peroxide in human cells. Cancer Res 1997; 57: 3963-3971.

[64] FU J, YUAN D, XIAO L, TU W, DONG C et al. The crosstalk between $\alpha$-irradiated Beas-2B cells and its bystander U937 cells through MAPK and NF- $\mathrm{KB}$ signaling pathways. Mutat Res 2016; 783: 1--8. https://doi.org/10.1016/j.mrfmmm.2015.11.001

[65] LAM RK, HAN W, YU KN. Unirradiated cells rescue cells exposed to ionizing radiation: Activation of NF- $\kappa \mathrm{B}$ pathway in irradiated cells. Mutat Res 2015; 782: 23-33. https://doi. org/10.1016/j.mrfmmm.2015.10.004

[66] BOYD M, SORENSEN A, MCCLUSKEY AG, MAIRS RJ. Radiation quality-dependent bystander effects elicited by targeted radionuclides. J Pharm Pharmacol 2008; 60: 951-958. https://doi.org/10.1211/jpp.60.8.0002

[67] PAILLAS S, BOUDOUSQ V, PIRON B, KERSUAL N, BARDIES $M$ et al. Apoptosis and p53 are not involved in the anti-tumor efficacy of (125)I-labeled monoclonal antibodies targeting the cell membrane. Nucl Med Biol 2013; 40: 471-480. https://doi.org/10.1016/j.nucmedbio.2013.02.001

[68] PAILLAS S, LADJOHOUNLOU R, LOZZA C, PICHARD A, BOUDOUSQ $\mathrm{V}$ et al. Localized irradiation of cell membrane by auger electrons is cytotoxic through oxidative stressmediated nontargeted effects. Antioxid Redox Signal 2016; 25: 467-484. https://doi.org/10.1089/ars.2015.6309

[69] BOYD M, ROSS SC, DORRENS J, FULLERTON NE, TAN KW et al. Radiation-induced biologic bystander effect elicited in vitro by targeted radiopharmaceuticals labeled with $\alpha-, \beta-$, and auger electron-emitting radionuclides. J Nucl Med 2006; 47: 1007-1015.

[70] WIDEŁ M, PRZYBYSZEWSKI WM. Inverse dose-rate effect for the induction of micronuclei in Lewis lung carcinoma after exposure to cobalt-60 gamma rays. Radiat Res 1998; 49: 98-102. https://doi.org/10.2307/3579686

[71] PRZYBYSZEWSKI WM, WIDE€ M, SZURKO A, MANIAKOWSKI Z. Dose rate-dependent cellular and molecular effects of ionizing radiation. Postepy Hig Med Dosw 2008; 62: 468-477. 
[72] KISHIKAWA H, WANG K, ADELSTEIN SJ, KASSIS AI. Inhibitory and stimulatory bystander effects are differentially induced by Iodine-125 and Iodine-123. Radiat Res 2006; 165: 688-694. https://doi.org/10.1667/RR3567.1

[73] MOTHERSILL C, SEYMOUR CB, JOINER MC. Relationship between radiation-induced low-dose hypersensitivity and the bystander effect. Radiat Res 2002; 157: 526-532. https://doi.org/10.1667/0033-7587(2002)157[0526:RBRIL D]2.0.CO;2

[74] NUTA O, DARROUDI F. The impact of the bystander effect on the low-dose hypersensitivity phenomenon. Radiat Environ Biophys 2008; 47: 265-274. https://doi.org/10.1007/s00411$\underline{007-0145-9}$

[75] MARPLES B, WOUTERS BG, COLLIS SJ, CHALMERS AJ, JOINER MC. Low-dose hyper-radiosensitivity: a consequence of ineffective cell cycle arrest of radiation-damaged G2-phase cells. Radiat Res 2004; 161: 247-255. https://doi.org/10.1667/ RR3130

[76] KRUEGER SA, JOINER MC, WEINFELD M, PIASENTIN E, MARPLES B. Role of apoptosis in low-dose hyper-radiosensitivity. Radiat Res 2007; 167: 260-267. https://doi.org/10.1667/ $\underline{\text { RR0776.1 }}$

[77] FRIESEN C, LUBATSCHOFSKI A, KOTZERKE J, BUCHMANN I, RESKE S, DEBATIN K. Beta-irradiation used for systemic radioimmunotherapy induces apoptosis and activates apoptosis pathways in leukaemia cells. Eur J Nucl Med Mol Imaging. 2003; 30: 1251-1261. https://doi.org/10.1007/ s00259-003-1216-Z

[78] REN R, HE M, DONG C, XIE Y, YE S et al. Dose response of micronuclei induced by combination radiation of $\alpha$-particles and $\gamma$-rays in human lymphoblast cells. Mutat Res 2013; 741742: 51-56. https://doi.org/10.1016/j.mrfmmm.2012.12.007

[79] KUMAR C, JAYAKUMAR S, PANDEY BN, SAMUEL G, VENKATESH M. Cellular and molecular effects of beta radiation from I-131 on human tumor cells: a comparison with gamma radiation. Curr Radiopharm 2014; 7: 138-143. https://doi.org/10.2174/1874471007666140716115938

[80] XUE LY, BUTLER NJ, MAKRIGIORGOS GM, ADELSTEIN SJ, KASSIS AI. Bystander effect produced by radiolabeled tumor cells in vivo. Proc Natl Acad Sci USA 2002; 99: 1376513770. https://doi.org/10.1073/pnas.182209699

[81] SHUSTERMAN S, GRANT FD, LORENZEN W, DAVIS RT, LAFFIN S et al. Iodine-131-labeled meta-iodobenzylguanidine therapy of children with neuroblastoma: program planning and initial experience. Semin Nucl Med 2011; 41: 354-363. https://doi.org/10.1053/j.semnuclmed.2011.06.001

[82] YEONG CH, CHENG M, NG KH. Therapeutic radionuclides in nuclear medicine: current and future prospects. J Zhejiang Univ Sci B 2014; 15: 845-863. https://doi.org/10.1631/jzus. $\underline{B 1400131}$

[83] MITROFANOVA E, HAGAN C, QI J, SEREGINA T, LINK C Jr. Sodium iodide symporter/radioactive iodine system has more efficient antitumor effect in three-dimensional spheroids. Anticancer Res 2003; 23: 2397-2404.

[84] RUDQVIST N, PARRIS TZ, SCHULER E, HELOU K, FORSSELL-ARONSSON E. Transcriptional response of BALB/c mouse thyroids following in vivo astatine-211 exposure reveals distinct gene expression profiles. EJNMMI Res 2012; 2: 32. https://doi.org/10.1186/2191-219X-2-32

[85] GRIDLEY DS, WILLIAMS JR., SLATER JM. Low-dose/ low-dose rate radiation: a feasible strategy to improve cancer radiotherapy? Cancer Ther 2005; 3: 105-130.

[86] KUMAR C, SHETAKE N, DESAI S, KUMAR A, SAMUEL $\mathrm{G}$ et al. Relevance of radiobiological concepts in radionuclide therapy of cancer. Int J Radiat Biol 2016; 92: 173-186. https:// doi.org/10.3109/09553002.2016.1144944

[87] SGOUROS G, ROESKE JC, MCDEVITT MR, PALM S, ALLEN BJ et al. MIRD Pamphlet No. 22 (abridged): radiobiology and dosimetry of alpha-particle emitters for targeted radionuclide therapy. J Nucl Med 2010; 51: 311-328. https://doi. org/10.2967/jnumed.108.058651

[88] CHOUIN N, BERNARDEAU K, BARDIES M, FAIVRECHAUVET A, BOURGEOIS $M$ et al. Evidence of extranuclear cell sensitivity to alpha-particle radiation using a microdosimetric model. II. Application of the microdosimetric model to experimental results. Radiat Res 2009; 171: 664-673. https:// doi.org/10.1667/RR1536.1

[89] PONNAIYA B, JENKINS-BAKER G, BIGELOW A, MARINO S, GEARD CR. Detection of chromosomal instability in alpha-irradiated and bystander human fibroblasts. Mutat Res 2004; 568: 41-48. https://doi.org/10.1016/j. mrfmmm.2004.06.045

[90] GAILLARD S, PUSSET D, DE TOLEDO SM, FROMM M, AZZAM EI. Propagation distance of the alpha-particleinduced bystander effect: the role of nuclear traversal and gap junction communication. Radiat Res 2009; 171: 513-520. https://doi.org/10.1667/RR1658.1

[91] BELYAEV IY, ALIPOBV YED, MATRONCHIK AYU. Cell density dependent response of E. coli cells to weak ELF magnetic fields. Bioelectromagnetics 1998; 19: 300-309. https:// doi.org/10.1002/(SICI) 1521-186X(1998)19:5<300::AIDBEM4>3.0.CO;2-5

[92] SHCHEGLOV VS, ALIPOV ED, BELYAEV IY. Cell-to-cell communication in response of E. coli cells at different phases of growth to low-intensity microwaves. Biochim Biophys Acta 2002; 1572:101-106. https://doi.org/10.1016/S03044165(02)00283-0

[93] ALIPOV ED, SHCHEGLOV VS, SARIMOV RM, BELYAEV IY. Cell-density dependent effects of low-dose ionizing radiation on E. coli cells. Radiats Biol Radioecol 2003; 43: 167-171.

[94] BELYAEV IY, HARMS-RINGDAHL M. Effects of gamma rays in the $0.5-50 \mathrm{cGy}$ range on the conformation of chromatin in mammalian cells. Radiat Res 1996; 145: 687-693. https://doi. org/10.2307/3579359

[95] KADHIM MA, LEE R, MOORE SR, MACDONALD DA, CHAPMAN KL et al. Genomic instability after targeted irradiation of human lymphocytes: evidence for inter-individual differences under bystander conditions. Mutat Res 2010; 688: 91-94. https://doi.org/10.1016/j.mrfmmm.2010.03.013

[96] HU B, ZHU J, ZHOU H, HEI TK No significant level of inheritable interchromosomal aberrations in the progeny of bystander primary human fibroblast after alpha particle irradiation. Adv Space Res 2013; 51: 450-457. https://doi. org/10.1016/j.asr.2012.09.020 
[97] SIVA S, MACMANUS MP, MARTIN RF, MARTIN OA. Abscopal effects of radiation therapy: A clinical review for the radiobiologist. Cancer Lett 2015; 356: 82-90. https://doi. org/10.1016/j.canlet.2013.09.018

[98] FORMENTI SC, DEMARIA S. Combining radiotherapy and cancer immunotherapy: A paradigm shift. J Natl Cancer Inst 2013; 105: 256-265. https://doi.org/10.1093/jnci/djs629

[99] CRITTENDEN M, KOHRT H, LEVY R, JONES J, CAMPHAUSEN K et al. Current clinical trials testing combinations of immunotherapy and radiation. Semin Radiat Oncol 2015; 25: 54-64. https://doi.org/10.1016/j.semradonc.2014.07.003

[100] HANNA GG, COYLE VM, PRISE KM. Immune modulation in advanced radiotherapies: targeting out-of-field effects. Cancer Lett 2015; 368: 246-251. https://doi.org/10.1016/j. canlet.2015.04.007

[101] REYNDERS K, ILLIDGE T, SIVA S, CHANG JY, DE RUYSSCHER D. The abscopal effect of local radiotherapy: Using immunotherapy to make a rare event clinically relevant. Cancer Treat Rev 2015; 41: 503-510. https://doi.org/10.1016/j. ctrv.2015.03.011

[102] DONG C, HE M, TU W, KONISHI T, LIU W et al. The differential role of human macrophage in triggering secondary bystander effects after either gamma-ray or carbon beam irradiation. Cancer Lett 2015; 363: 92-100. https://doi. org/10.1016/j.canlet.2015.04.013

[103] GHODADRA A, BHATT S, CAMACHO JC, KIM HS. Abscopal Effects and Yttrium-90 Radioembolization. Cardiovasc Intervent Radiol 2015; 39: 1076-1080. https://doi.org/10.1007/ $\underline{\text { s00270-015-1259-0 }}$

[104] KENNEDY AS, NUTTING C, COLDWELL D, GAISER J, DRACHENBERG C. Pathologic response and microdosimetry of $90 \mathrm{Y}$ microspheres in man: review of four explanted whole livers. Int J Radiat Oncol 2004; 60: 1552-1563. https:// doi.org/10.1016/j.ijrobp.2004.09.004 